\title{
DEVELOPMENT OF THE SOCIALLY-ORIENTED ECONOMY IN UKRAINE: PREREQUISITES AND STRATEGIC FORECASTING
}

\author{
Nataliia KRAVCHUK' \\ Zhytomyr National Agroecological University, Ukraine \\ Liudmyla TARASOVYCH ${ }^{2}$ \\ Zhytomyr National Agroecological University, Ukraine \\ Maryna YAREMOVA ${ }^{3}$ \\ Zhytomyr National Agroecological University, Ukraine
}

\begin{abstract}
The purpose of this article is to substantiate prerequisites and prospects for the formation and development of the socially-oriented economy in Ukraine. The theoretical and methodological background to the research is system and synergetic scientific approaches, which use in the research of the development of a socially-oriented economy is determined by orientation to basic values and fundamentals of the market economic system and focus on building a democratic society in Ukraine. Scientific results - it is substantiated that in modern conditions of transformational changes, a strategic course of Ukraine is to combine mechanisms of market selfregulation and state regulation, which in its basis is based on principles of socially-oriented economy. Such a model of the economy is focused on a human along with its needs and interests, relations with other members of society during production, distribution, exchange, and consumption. At the same time, social orientation foresees providing high productive economic management that configures private initiative and competition. Results of conducted analysis of analytical indicators of socio-economic development of Ukraine show an urgent necessity and objectivity of forming a socially-oriented economy. It is proved that taking into account increase in openness of the national economy, it is appropriate to consider strict conditions concerning its adequacy to requirements of the current international competition. In this relation, there are analysed vectors of the formation of the socially-oriented economy in Ukraine declared by the Strategy of Sustainable Development "Ukraine 2020 " within which a key reference point is an introduction in the country of European standards of living and its achieving a dominant position in the world. An economic platform of the formation and development of the socially-oriented economy is determined the following: providing economic freedom; availability of different types of business; development of competition; formation of a free pricing mechanism; creation of market and social infrastructure; formation of a model of the open economy. In addition, tools and measures of socioeconomic policy of the state are: transparency of activities of public authorities at all levels; focus of investment flows on an implementation of the nation's social potential and improvement of the population quality of life; priority of development of a transparent competitive area; demonopolization of business environment; strict control over the compliance with the international practical requirements; successive narrowing a sphere of influence of shadow economy and rooting out corruption; power consolidation and efficient cooperation of all its branches; solving a problem of a conflict in the southeast of Ukraine. Practical implication of the scientific results lies in the fact that the substantiated prerequisites and prospects for the formation and development of socially-oriented economy in Ukraine will contribute to the organization of public production that will combine efficiency of market mechanism and principles of self-organization on the basis of accentualization on achieving high standard of living for all segments of the population.
\end{abstract}

Key words: socially-oriented economy, society, model, prerequisites of formation, development prospects.

JEL Classification: A14, H41

\footnotetext{
Corresponding author:

${ }^{1}$ Department of Economics and Entrepreneurship, Zhytomyr National Agroecological University.

E-mail: faulbeere@ukr.net

${ }^{2}$ Department of Marketing, Zhytomyr National Agroecological University.

E-mail: luda2310@i.ua

${ }^{3}$ Department of Economics and Entrepreneurship, Zhytomyr National Agroecological University.

E-mail: marinel82@ukr.net
} 


\section{Introduction}

A qualitatively new level of development of the national economy is determined by development and introduction of a working model of its economic system. Dual nature of such a model envisages, on the one hand, taking into account a positive world experience in management of society and harmonization of state and market mechanisms of economic regulation, and on the other - acceleration of implementation of a strategic aim -achievement of high standard of living for all segments of the population. Today, the development of socially-oriented economy is under way in developed countries that occurred as a result of transformation of market economy under the influence of globalization and internationalization and is based on principles of productive work and favourable conditions for it, combination of values of an individual activity concerning the rise in living standards and selfrealization for the good of society.

Formation of the economic system of a qualitatively new level and providing its balanced development are extremely important for the future of Ukraine. Current, a low one according to the European standards, the social standard of living, polarization in incomes of different segments of the population are one of the causes of underdevelopment of "middle class", low level of trust of Ukrainian citizens to all government institutions. Levelling of social pessimism and apathy on the basis of new social and economic standards will provide guarantees for the sustainable development of Ukrainian democracy and Ukrainian statehood as such. Taking the above mentioned into consideration, a substantiation of prerequisites and prospects for the formation and development of the socially-oriented economy in Ukraine is seen as necessary not only from the scientific point of view but also a practical one.

\section{Current state of the problem research}

A concept of "social market economy" has obtained a gradual implementation in a model of "social marketbased economy" in Germany. Ludwig Erhard in his work "Prosperity for All" determined the main key factors of economic renovation - free private initiative and competition in conjunction with an active role of the state (Erhard, 1948). Economic and social "order" established in FRG was called "synthesis of a new type" and it clearly outlined boundaries of the state power activities in the economy for the purpose of preventing undesirable effects of a "chaotic development" and also avoiding the formation of the central administrative system. A key idea of a new order was to create free, economically efficient, socially just economic and public "order" (Pytannia nimetskoi istorii, 2014). Economic order (Wirtschaftsordnung) - is a central concept of German economic thought over the past 50 years. It was introduced by W. Eucken - one of the founders of the theory of "social market economy" which the author understands as a body of rules, first of all legal, where economic and social processes have to take place, and he puts social just on a par with economic freedom and free enterprise (Oiken, 1995). The model of the social market economy has to provide free, efficient, stable status in society and economy that guarantees economic freedom, market methods of economic management, competition and herewith provides a social security system and social justice (Babichev, 2001).

Issues of the formation of the socially-oriented national economy in Ukraine are considered in works of such scientists as: O. Bondar-Pidhurska (Bondar-Pidhurska, 2015), N. Hrynchuk (Hrynchuk, 2003), V. Hryshkin (Hryshkin, 2005), N. Dieieva (Dieieva, 2001), O. Lozova (Lozova, 2014), O.Makara (Makara, 2012), H. Onyshchuk (Onyshchuk, 2012), O. Serhiienko (Serhiienko, 2002), N. Tereshchenko (Tereshchenko, 2010) and others. Fundamental research on this issue are made by Russian scientists, in particular, L. Abalkin (Abalkin, 2005), A. Butkovskyi (Butkovskii, 2001), A. Babychev (Babichev, 2001). A special attention should be paid to the results of scientific research of R. M. Nurieiev who puts an emphasis on an urgent necessity to create institutional conditions similar to "social market economy" of Germany in the formation of market economy of Russia and, in turn, substantiates advantages and possibilities of this model of development (Nurieiev, 2002). Considering the fact that the model of the socially-oriented economy must be built taking into account national features of a certain country, in the context of this research, there are good reasons to substantiate prerequisites and prospects for its formation and development through the prism of such features in Ukraine.

\section{Substantiation of the essence of socially-oriented economy}

Adoption of the Declaration of State Sovereignty of Ukraine and Act of Declaration of Independence of Ukraine in due course practically initiated the formation of fundamentals of the state policy oriented to democratic development of the state and prospects for social development. At the same time, a process of further democratic development of radical changes in the country on all its fronts is constantly under way. Creation of an efficient system of public authorities, working social protection system, and development of civil society are still the main tasks of Ukrainian state (Tytarenko, 2010).

Social orientation of the economy of Ukraine provides securing high productive economic management that configures private initiative and competition. National competitiveness in the long term can be provided by intensive reproduction of human capital and formation of the middle class of citizens with increasing quality of life. If full-fledged economy lies in the basis, it is possible 


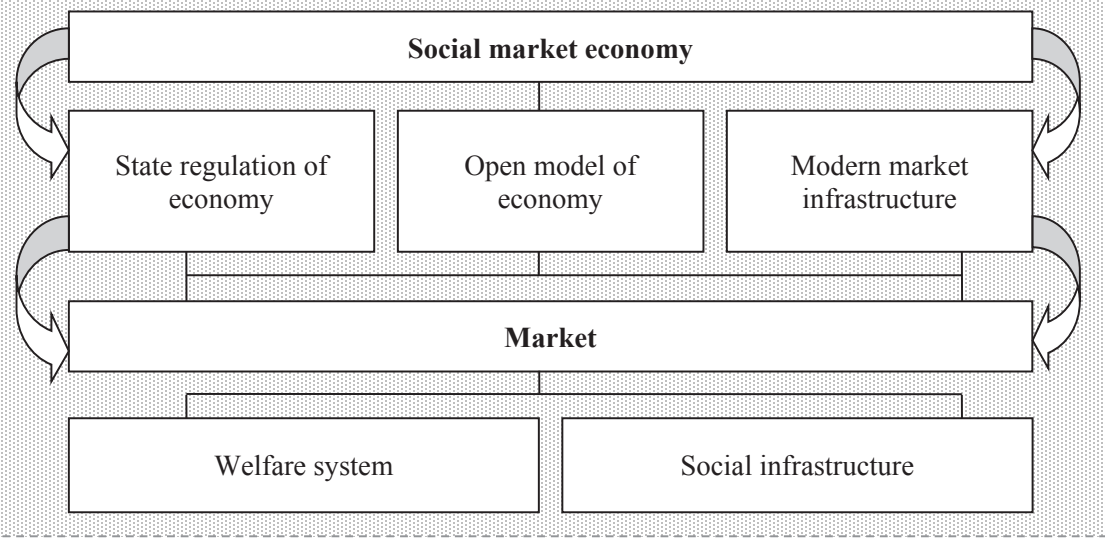

Fig. 1. Specific features of social market economy

Source: the author's research

to form a balanced system of social protection of the population, provide equal opportunities for access to universal human values. Social market economy is oriented to the achievement of a set of goals, which implementation will enable improving the quality of life of the population and sustainable economic growth of the country as a whole. Key goals of social market economy should be considered as the following: economic freedom (opportunities of economic entities to choose a field of activities and model of economic behaviour); economic growth (growth of economy that provides high level of quality of living of the population); formation of efficient and socially just monetary system; social security and social progress; equitable taxation (setting privileges in the taxation for population groups with low incomes); environmental and food security.

A strategic direction of the social market economy is: efficient system of property relations; monetary and exchange order; competitive, financial, tax, foreign economic orderliness, and also order in the field of labour and social relations. The use of market methods of economy, state regulation and forecast of the economy, open model of the economy, availability of modern market and social infrastructure, welfare system etc. are peculiar to the social market economy. The interrelation between components of the social market economy is shown in Fig. 1.

\section{Analytical study of the level of socio- economic development of Ukraine}

A readiness of transition of Ukraine to the sociallyoriented economy can be shown by indicators that characterize the level of economic development of the country such as GDP per capita, volume, and indices of

Table 1

The main indicators of socio-economic development of Ukraine

\begin{tabular}{|c|c|c|c|c|}
\hline \multirow{2}{*}{ Indicator } & \multicolumn{3}{|c|}{ Year } & \multirow{2}{*}{2016 vs. $2000, \%$} \\
\hline & 2000 & 2010 & $2016^{*}$ & \\
\hline Present population size, million people & 49,4 & 45,9 & 42,8 & 86,6 \\
\hline GDP per capita, UAH & 3436 & 24429 & 46201 & in 13 times \\
\hline Sold production of industry, billion UAH & 155,9 & 792,9 & 1565,3 & in 10 times \\
\hline Sold production of agriculture, billion UAH & 65,1 & 184,9 & 631,1 & in 9,6 times \\
\hline The number of registered unemployed, thousand people & 1008,1 & 544,9 & 390,8 & 38,8 \\
\hline Average monthly nominal wage per employee, UAH & 304,90 & 2239 & 5070 & in 16,6 times \\
\hline Real wage compared with previous year, $\%$ & $\mathrm{x}$ & 110,2 & 79,8 & $\mathrm{x}$ \\
\hline Average monthly pension, UAH & 68,9 & 1032,6 & 1699,5 & in 2,5 times \\
\hline Backdated wages - total, million UAH & 2996,7 & 1218,1 & 2004,0 & 66,9 \\
\hline Monthly minimum living wage per capita, UAH & 270 & 825 & 1544 & in 5,7 times \\
\hline Inflation index, \% (annual average growth rate) & 128 & 109,4 & 112,4 & - \\
\hline Consumer price index compared with previous year & 128,2 & 109,4 & 113,9 & - \\
\hline $\begin{array}{l}\text { Number of families who received accommodation during the } \\
\text { year, thousand }\end{array}$ & 32 & 11 & $\mathrm{x}$ & - \\
\hline Number of medical institutions, thousand & 3,3 & 2,8 & 1,7 & 51,5 \\
\hline Foreign direct investment in Ukraine's economy, million USD & 3865,5 & 5851,2 & 4405,8 & 114,0 \\
\hline Export of goods and services, million USD & 14948,4 & 46129,6 & 32734,4 & 219 \\
\hline Import of goods and services, million USD & 14286,9 & 54087,6 & 35058,7 & 245 \\
\hline Net balance $(+,-)$, million USD & 661,5 & $-7958,0$ & $-2324,3$ & - \\
\hline Crime rate, $\%$ of prison population to the general population & 0,5 & 0,4 & 0,2 & $\mathrm{x}$ \\
\hline
\end{tabular}

${ }^{*}$ Note: without consideration of temporarily occupied territory of the Autonomous Republic of Crimea and Sevastopol and anti-terrorist operation zone.

Source: calculated by data (Osnovni pokaznyky ekonomichnoho i sotsialnoho rozvytku Ukrainy, 2016; Sotsialni indykatory rivnia zhyttia naselennia, 2016; Tablytsia indeksiv infliatsii, 2016; Chyselnist naiavnoho naselennia Ukrainy, 2016). 
industrial and agricultural production, unemployment level, inflation index, foreign economic net balance, and so on. Thus, positive characteristics of the national economy was the renewal of high rates of economic growth in 2016 that is characterized by GDP volume per capita - in 13 times. Volumes of industrial production have increased in 10 times over the last 16 years, mainly at the expense of the growth in such branches of the economy as mining, processing industries, machine building, paper-and-pulp industry, metallurgy, foodstuff industry etc. Agriculture demonstrates the same result the growth in 9,6 times (Table 1).

The main result of positive economic dynamics is the fact that in Ukraine, an active social orientation of economic development is rooted. The main indicators of level and quality of living of the population are nominal wage increase in 16,6 times for the studied period, however, real wage does not correspond to growth rates of the first one. The negative factor is annual growth of consumer price index. Monthly average wage is now three times higher than a living wage. Therewith, backdated wages reduced by $33 \%$. Important indicators of social security services are the development of service industry, in particular, housing per capita, educational institutions, medical institutions etc. In this view, considerable volumes of investment resources for the renewal of destroyed facilities of the social infrastructure, especially in rural areas, are necessary. Thus, according to data of the State Statistics Service of Ukraine, there is annual reduction in public health institutions - at least twice, intensive closure of village schools, not well-established housing construction, in consequence of which young families have no opportunities to satisfy their need for housing that in developed countries rank with food, clothes, education, health demand etc. A feature of 2016 was a significant deterioration of foreign trade balance net balance amounts to 2324,3 million USD. Energy intensity of the national production and own energy resource shortage cause the expected rising cost of energy import that will leave the problem of foreign trade imbalance relevant for the future.

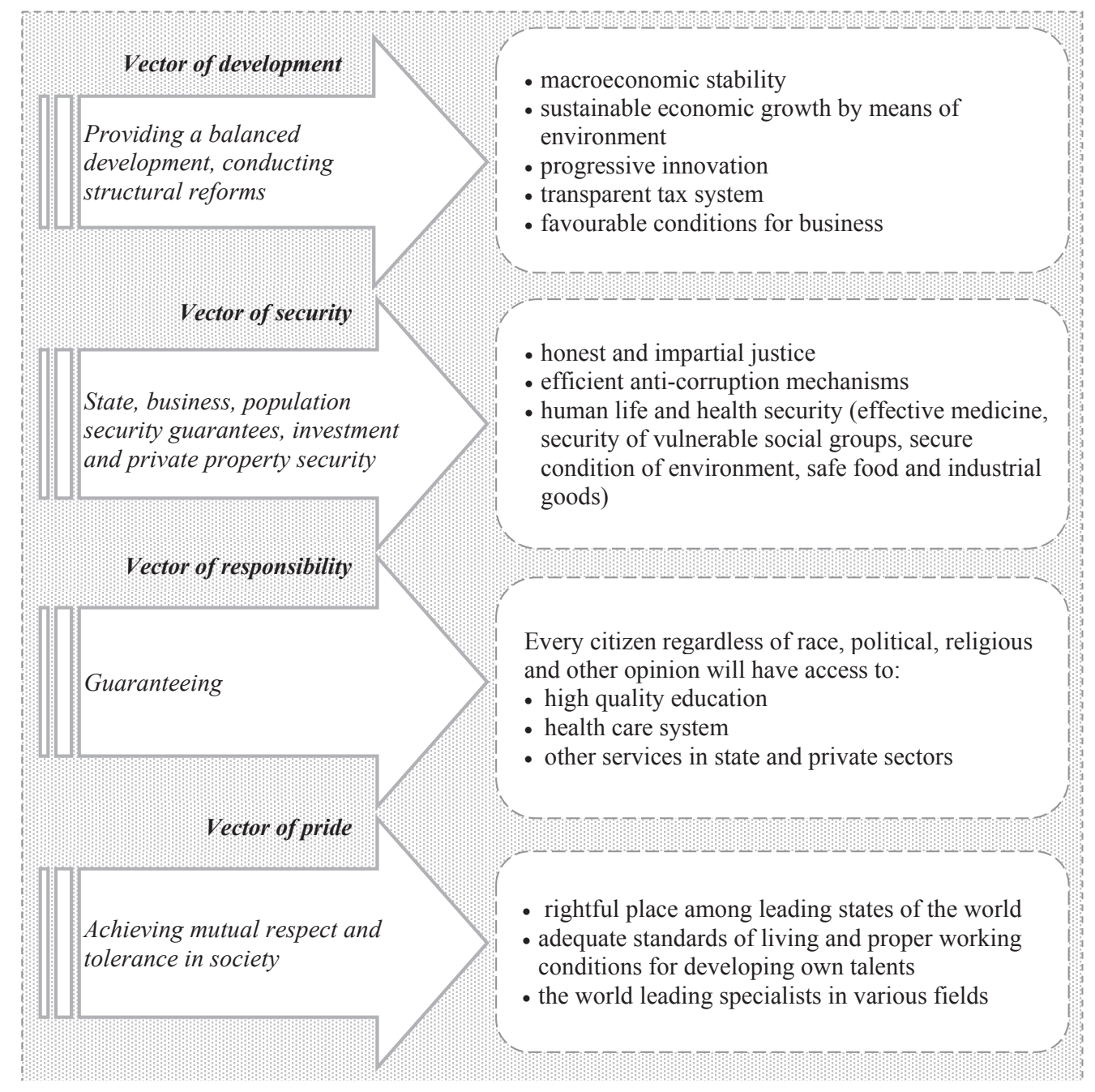

Fig. 2. Vectors of the formation of socially-oriented economy in Ukraine until 2020

Source: made by data (Pro Stratehiiu staloho rozvytku, 2015) 


\section{Economic platform of the socially-oriented economic development}

Taking into account Ukraine's striving for integration in the world economic and legal environment, increasing the openness of the national economy, it is necessary to consider hard terms concerning its adequacy to the requirements of contemporary international competitiveness and search for a proper place in the world and regional labour specialization. Indeed, the Government of the country made a lot of steps towards the international business networking. In particular, the Presidential Decree "On Sustainable Development Strategy "Ukraine - 2020" determines the main goal of the government for the foreseeable future - introduction of European living standards in the country and Ukraine's achieving leading position in the world (Pro Stratehiiu staloho rozvytku, 2015). Important vectors of the implementation of the above mentioned are the following socio-economic transformations (Fig. 2).
Today, conditions for the transition to the sociallyoriented market economy are engendering in Ukraine. In this relation, there is a pressing need of just economic and institutional preconditions that can become the basis for the transition from the post-crisis raising to the stage of dynamic development within the market socially-oriented development model. These preconditions can include: 1) providing economic freedom; 2) availability of different types of business; 3) development of competition; 4) formation of a free pricing mechanism; 5) creation of market and social infrastructure; 6) formation of a model of the open economy. The key tools and measures of socio-economic policy of the state are: transparency of activities of public authorities at all levels; focus of investment flows on an implementation of the nation's social potential and improvement of the population quality of life; priority of development of a transparent competitive area; demonopolization of business environment; strict

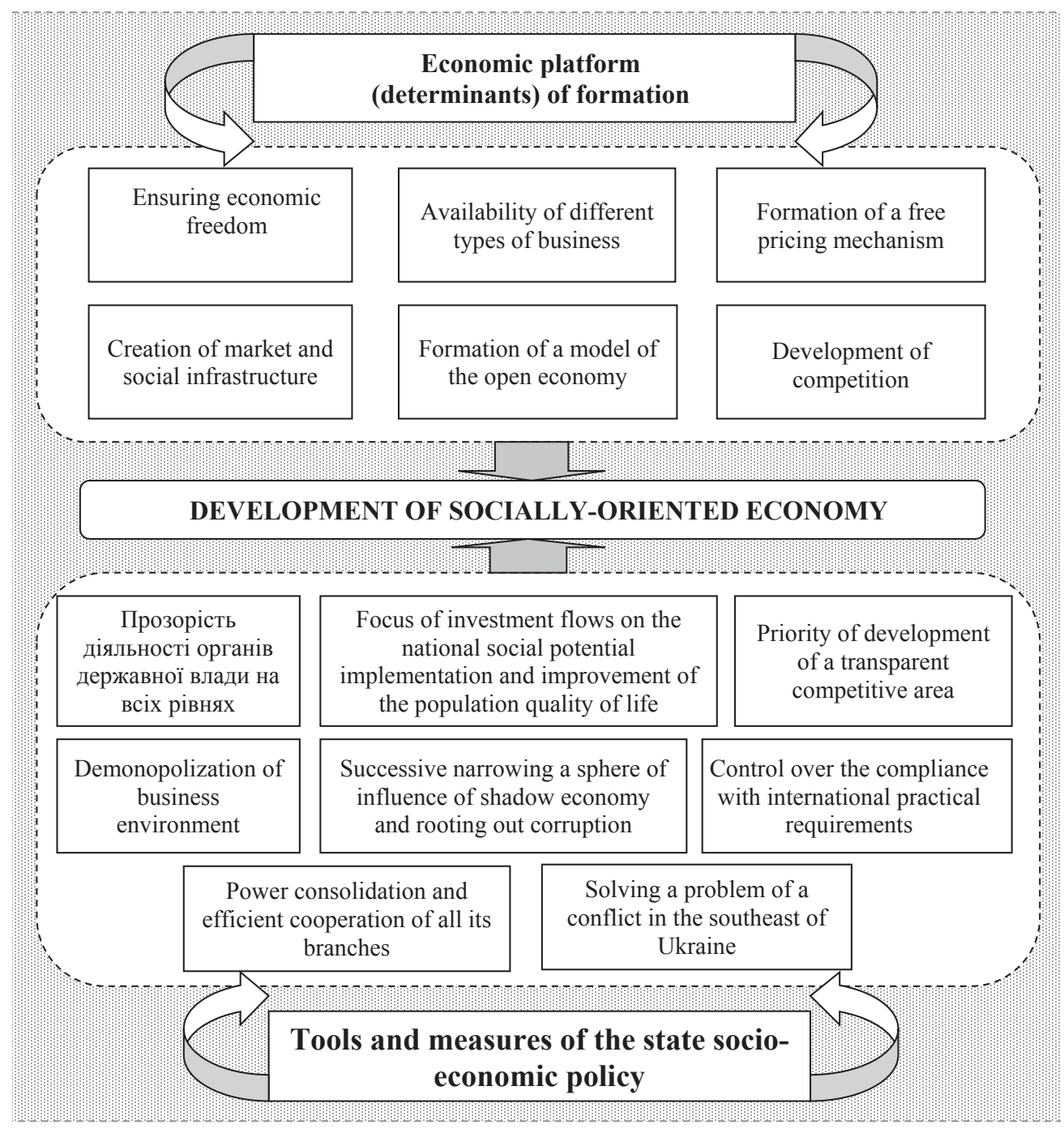

Fig. 3. Substantiation of prerequisites for the development of socially-oriented economy of Ukraine Source: generalized by the authors based on data of studied sources 
control over the compliance with the international practical requirements; successive narrowing a sphere of influence of shadow economy and rooting out corruption; power consolidation and efficient cooperation of all its branches; solving a problem of a conflict in the southeast of Ukraine (Fig. 3).

\section{Conclusions and prospects for further research}

The market economy development should be considered in the context of the national economic policy, which indicators of performance evaluation are an increase in competitiveness and formation of a favourable business platform for the development of the socio-oriented economy. This economy should be seen as the most perspective model of organization of social production, which that configures high efficiency of the market mechanism and orientation to achieving justice and equality. The model of the socially-oriented economy must be built taking into account national features of Ukraine that will allow bringing to nought threatening trends of the society fragmentation, social disappointment, loss of feeling of participation in shaping the future of the own state. Prospects for future research are substantiation of the model of sociallyoriented development of Ukraine in terms of integration to the European economic space.

\section{References:}

Abalkin L. I. (2005). Rossiia: poisk samoopredeleniia. Ocherki. Moskva: Nauka, 464 p.

Babichev A. V. (2001). Kedinoi geometricheskoi teorii upravleniia. Moskva: Nauka, p. 60-61.

Bartenev S. A. Istoriia ekonomicheskih uchenii v voprosah i otvetah. Ekonomicheskaia kontseptsiia i reforma L. Erharda. [Electronic resource]. - Available at: http://www.bibliotekar.ru/istoria-economicheskihucheniy-1/ 106.htm

Bondar-Pidhurska O. V. (2015). Rozrobka kontseptualnoi modeli systemy upravlinnia stalym innovatsiinym sotsialnooriientovanymrozvytkom ekonomiky Ukrainy. Visnyk KrNU imeni Mykhaila Ostrohradskoho. Vyp. 6 (95), Ch. 2, p. 25-32.

Hrynchuk N. (2003). Sutnist poniattia “sotsializatsiia ekonomiky”. Upravlinnia suchasnym mistom, №7-9(11), p. 17.

Hryshkin V. O. (2005). Sotsializatsiia ekonomiky Ukrainy: teoriia, metodolohiia, perspektyvy: monohrafiia. Dnipropetrovsk : Porohy, $498 \mathrm{p}$.

Dieieva N. (2001). Kontseptsiia sotsialnoi derzhavy v realiiakh i perspektyvakh zaprovadzhennia v Ukraini. Ekonomika: problemy teorii ta praktyky: Zbirnyk nauk. prats. Vyp. 115, p. 3-14.

Lozova O. V. (2014). Kontseptualni zasady sotsialnoho rozvytku v umovakh sotsialno oriientovanoi rynkovoi ekonomiky Ukrainy. Naukovyi visnyk Khersonskoho derzhavnoho universytetu. Vyp. 6, ch. 2, p. 242-245.

Makara O. V. (2012). Strukturni transformatsii u sotsialno oriientovanii natsionalnii ekonomitsi. Naukovyi visnyk natsionalnoho lisotekhnichnoho universytetu Ukrainy: zbirnyk naukovo-tekhnichnykh prats. Lviv: RVV NLTU Ukrainy. Vyp. 22.15, p. 261-270.

Oiken V. (1995). Osnovnye printsipy ekonomicheskoi politiki. Perevod s nemetskogo L.A. Kozlova i Yu.I. Kukoleva. Obshchaia redaktsiia L.I. Tsedilina i K. Herrmann-Pillata. Vstupitelnaia statia O.R. Latsisa. (Moskva: Izdatelskaia gruppa «Progress», Firma «Univers»,- Seriia «Ekonomicheskaia mysl Zapada»).

Onyshchuk H. I. Kontseptualni zasady sotsialno-ekonomichnoho rozvytku rehioniv Ukrainy [Electronic resource]. - Available at: http://khg.kname.edu.ua/index.php/khg/article/viewFile/1620/1612

Osnovni pokaznyky ekonomichnoho i sotsialnoho rozvytku Ukrainy. - statystychnyi zbirnyk Ministerstva ekonomichnoho rozvytky i torhivli Ukrainy [Electronic resource]. - Available at: http://www.me.gov.ua/

Documents Pytannia nimetskoi istorii [Tekst] : zb. nauk. pr. / vidp. red. S. Y. Bobylieva. - D. : Lira, 2014. - 328 p. [Electronic resource]. - Available at: http://www.dnu.dp.ua/docs/zbirniki/fistor/program_56cd7c17765d0.pdf Pro Stratehiiu staloho rozvytku «Ukraina - 2020» / Ukaz Prezydenta Ukrainy № 5/2015 vid 12 sichnia 2015 roku [Electronic resource]. - Available at: http://www.ukrstat.gov.ua/ http://zakon3.rada.gov.ua/laws/show/5/2015 Serhiienko O. (2002). Sotsialna polityka v suchasnomu sviti ta v Ukraini. Ukraina: aspekty pratsi. № 1, p. 31-37. Sotsialni indykatory rivnia zhyttia naselennia. - Statystychnyi zbirnyk Derzhavnoi sluzhby statystyky Ukrainy, 2016.

Tablytsia indeksiv infliatsii za 2000-2016 rr. [Electronic resource]. - Available at: https://buhgalter.com.ua/ dovidnik/norma-robochogo-chasu/tablitsya-indeksiv-inflyatsiyi.

Tereshchenko N.V. Innovatsiina sotsialno-oriientovana model rozvytku ekonomiky 2011 r. Ukrainy. [Electronicresource]. - Available at: http://www.nbuv.gov.ua/portal/soc_gum/pubupr/2010/2010-2/doc/4/.

Tytarenko L. (2010). Stanovlennia, rozvytok ta perspektyvy sotsialno oriientovanoi derzhavy v Ukraini. Humanitarnyi visnyk ZDIA. Vyp. 41, p. 132-140.

Chyselnist naiavnoho naselennia Ukrainy na 1 sichnia 2016 roku. - Statystychnyi zbirnyk Derzhavnoi sluzhby statystyky Ukrainy, 2016 [Electronic resource]. - Available at: http://www.ukrstat.gov.ua/

Erhard L. Blagosostoianie dlia vseh. [Electronic resource]. - Available at: http://www.e-reading.club/book. php?book $=67568$ 


\section{Наталия КРАВЧУК, ЛюДМила ТАРАСОВИЧ, Марина ЯРЕМОВА РАЗВИТИЕ СОЦИАЛЬНО ОРИЕНТИРОВАННОЙ ЭКОНОМИКИ В УКРАИНЕ: ПРЕДПОСЫЛКИ И СТРАТЕГИЧЕСКОЕ ПРЕДВИДЕНИЕ}

Аннотация.Цельюданной статьиявляется обоснованиепредпосылокиперспектив формированияиразвития социально ориентированной экономики в Украине. Теоретико-методологической основой исследования являются системный и синергетический подходы, использование которых в исследовании развития социально ориентированной экономики обусловлено ориентацией на базовые ценности и фундаментальные основы рыночной экономической системы и курсом на построение демократического общества в Украине. Результаты исследования - обосновано, что в современных условиях трансформационных изменений стратегическим курсом Украины является сочетание механизмов рыночного саморегулирования и государственногорегулирования,чтовсвоейосновеосновываетсянапринципахсоциальноориентированной экономики. Фокусом внимания такой модели экономики является человек с его потребностями и интересами, ее отношения с другими членами общества в процессе производства, распределения, обмена и потребления. При этом социальная ориентация предусматривает обеспечение высокопроизводительного хозяйствования, конфигурирует частную инициативу и конкуренцию. Результаты проведенного анализа аналитических показателей социально-экономического развития Украинысвидетельствуют о настоятельной необходимости и объективность формирования социально ориентированной экономики. Доказано, что учитывая рост открытости национальной экономики, целесообразным является учет жестких требований относительно ее адекватности требованиям современной международной конкуренции. В этой связи проанализированы векторы формирования социально ориентированной экономики в Украине, что задекларированные Стратегией устойчивого развития «Украина - 2020», в рамках которой ключевым ориентиром определено внедрения в стране европейских стандартов жизни и выход ее на ведущие позиции в мире. Экономической платформой формирования и развития социально ориентированной экономики являются: обеспечение экономической свободы; наличие различных организационно-правовых форм; развитие конкуренции; формирование механизма свободного ценообразования, создание рыночной и социальной инфраструктуры; формирование модели открытой экономики. Инструментами и мерами социально-экономической политики государства при этом являются: прозрачность деятельности органов государственной власти на всех уровнях; ориентация инвестиционных потоков на реализацию социального потенциала нации и повышения качества жизни населения; приоритетность развития прозрачного конкурентного поля; демонополизация бизнес-среды; жесткий контроль соответствия международным требованиям практики; последовательное сужение сферы влияния теневой экономики и искоренение коррупции; консолидация власти и эффективное взаимодействие всех ее ветвей; решение проблемы конфликта в юго-восточном регионе Украины. Практическое значение результатов исследования заключается в том, что обоснованные предпосылки и перспективы формирования и развития социально ориентированной экономики в Украине будут способствовать организации общественного производства, которая будет сочетать эффективность рыночного механизма и принципы самоорганизации на основе акцентуализации на достижении высокого уровня жизни для всех слоев населения. 